\title{
Хірургічні проблеми вторинного і третинного гіперпаратиреозу в діалізних паціентів із хронічною нирковою недостатністю
}

\begin{abstract}
Мета роботи: визначення поширенності гіперпаратиреозу у пацієнтів з хронічною нирковою недостатністю (ХНН), які проходили лікування з використанням діалізних технологій та аналіз результатів його хірургічного лікування.

Матеріали і методи. Дослідження проведено на основі вивчення медичної документації 89 пацієнтів, які лікувалися у відділенні нефрології міської клінічної лікарні № 2 міста Кривого Рогу за 2014-2018 рр. Всі пацієнти проходили лікування ХНН із застосуванням діалізних методів. Серед пацієнтів першої групи 66 (74,2\%) хворих були на гемодіалізі (Гд), другої - 23 (25,8 \%) на перитоніальному діалізі (ПД). За статтю в обох групах переважали чоловіки: відповідно 49 (55,1 \%) та 40 (44,9 \%) -

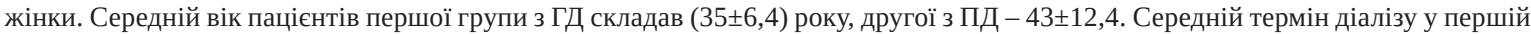
групі складав $(9,6 \pm 2,3)$ року, у другій - 5,4 $\pm 3,7$.

Результати досліджень та їх обговорення. Серед основних критеріїв до хірургічного лікування гіперпаратиреозу у діалізних пацієнтів визначено клінічні, лабораторні та інструментальні показники.
\end{abstract}

Ключові слова: хронічна ниркова недостатність; вторинний гіперпаратиреоз; третинний гіперпаратиреоз; паратиреоїдектомія.

Постановка проблеми і аналіз останніх досліджень та публікацій. В Україні останніми роками спостерігається неухильне зростання кількості хворих на хронічну хворбу нирок (XXН). Захворювання III-V стадії діагностовано в 31523 осіб, із них V - 9214 (21,9 на 100 тис. населення) [1]. Тяжким і постійним ускладненням ХХН $€$ порушення мінерального і кісткового обмінів зі зниженням рівня кальцію крові, що стимулює гіперплазію клітин прищитоподібних залоз (ПЩЗ) і зумовлює розвиток вторинного (ВГПТ) та третинного гіперпаратиреозу (ТГПТ). При цьому третинний гіперпаратиреоз $є$ наслідком прогресування вторинного гіперпаратиреозу і проявляється автономною гіперфункцією ПЩЗ із порушенням механізмів зворотного зв'язку між рівнем кальцію крові і рівнем продукції паратгормону та морфологічною перебудової залоз із формуванням аденоми. На сьогодні у світовій практиці успішно застосовують концепцію лікування хворих із термінальною стадією XXН, яка передбачає поєднання методик нирковозамісної терапії (НЗТ): гемодіалізу, перитонеального діалізу (ПД) і трансплантації [3]. Така лікувальна тактика дозволяє значно продовжити термін життя пацієнтів та відповідно збільшити кількість кількість пацієнтів з відповідним гіперпаратиреозом, що, у свою чергу, породжує проблему хірургічного лікування вказаного ускладнення. Незважаючи на значну ефективність консервативної терапї ХНН 0,3-14 \% діалізних пацієнтів потребують хірургічного лікування (Yeong-Hau H., 2005, Gourgiotis S., 2006). Паратиреоїдектомія є ефективним методом лікування ВГПТ і ТГПТ, але у 3-4 \% оперованих пацієнтів мають місце різноманітні післяопераційні ускладнення, а у 10-83 \% - спостерігається рецидив захворювання (Nada R. 2008, Mircescu G., 2010). Актуальними при цьому залишаются питання показань до хірургічного лікування, об’єм втручання та профілакти післяопераційних рецидивів.

Мета роботи: визначення поширенності гіперпаратиреозу у пацієнтів з хронічною нирковою недостатністю (ХНH), які проходили лікування з використанням діалізних технологій та аналіз результатів його хірургічного лікування.

Матеріали і методи. Дослідження проведено на основі вивчення медичної документації̈ 89 пацієнтів, які лікувалися у відділення нефрології міської клінічної лікарні № 2 міста Кривого Рогу за 2014-2018 рр. Всі пацієнти проходили лікування ХНH із застосуванням діалізних методів. Серед пацієнтів першої групи 66 (74,2 \%) хворих були на гемодіалізі (ГД), другої - 23 (25,8 \%) хворі - на перитоніальному діалізі (ПД). За статтю в обох групах переважали чоловіки: відповідно 49 (55,1%) та 40 (44,9 \%) - жінки. Середній вік пацієнтів першої групи з ГД складав $(35 \pm 6,4)$ року, другої з ПД

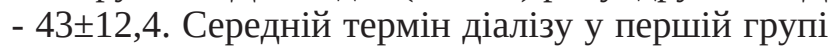
складав $(9,6 \pm 2,3)$ року, у другій $-5,4 \pm 3,7$.

Обстеження пацієнтів включало: оцінку загального статусу із анкетуванням скарг оцінкою якості до операції та після неї; загальний та біохімічний аналіз крові; визначення рівнів паратгормону, крові, іонізованого кальцію, фосфору та витаміну D - $25(\mathrm{OH}) \mathrm{D}_{3}$; УЗД черевної порожнини і нирок, УЗД щитоподібної (ЩЗ) та прищитоподібних залоз (Пщз). 
Результати дослідження та їх обговорення. Серед діалізних 89 пацієнтів за даними лабораторних досліджень у 35 (39,3 \%) хворих визначався гіперпаратиреоз із середнім рівнем паратогормону $(890 \pm 20,5)$ пг/мл. Серед даних пацієнтів у 8 (9 \%) визначалась гіперкальціємія у межах 2,65 ммоль/л.

Хірургічне лікування виконано 9 (10 \%) пацієнтам. Показаннями до хірургічного лікування вважали рекомендації Американської тиреоїдної асоціації (S. E. Carty, 2019): тяжкий ВГПТ, який не піддається консервативному лікуванню; рівень ПТГ вище 800 пг/мл; гіперкальцемія; кальцифілаксія з рівнем ГПТ вище 500 пг/мл; нефролітіаз; безсимптомна персистивна гіперкальцемія протягом більше року; наявність збільшення розмірів ПЩЗ при УЗД. Додатковими показаннями вважали наявність скарг: виражений больовий синдром кісток скелета (спостерігався у 98 \% пацієнтів із рівнем ПТГ вище 800 пк/мл) та порушення біомеханіки ходи (“качина хода” чи “важка хода” - у 28 \% пацієнтів); виражений свербіж шкіри (у 75 \% пацієнтів); наяність в анамнезі переломів кісток (у 35 \% пацієнтів). При УЗД у всіх 9 пацієнтів визначалось збільшення розмірів ПЩ3, у 2-х із них із сонографічними ознаками аденоми ПЩз.

Серед оперованих пацієнтів 8 знаходились на ГД та 1 пацієнтка на ПД. Важливою умовою для вирішення питання хірургічного лікування таких пацієнтів $є$ можливість проведення діалізу за день перед операцією та наступного дня після операції, а також виконана передопераційна підготовка 3 обов’язковою медикаментозною компенсацією дефіциту витаміну D. Таку можливість забезпечено на базі багатопрофільної міської клінічної лікарні, яка є базою ФПО Дніпропетровської медичної академії, де розташоване відділення нефрології, урології, ендокринної хірургії, хронічного та невідкладного діалізу.

На сьогодні у світі застосовують три варіанти хірургічного лікування з приводу ВГПТ і ТГПТ: субтотальна паратиреоїдектомія із залишком 5060 мг нормальної тканин ПЩ3; тотальна паратиреоїдектомія 3 автотрансплантацією тканини ПЩ3 (12-15 фрагментів подрібненої, найменш зміненої ПШ3) у внутрішньом'язові кишені кінцівок; тотальна паратиреоїдектомія без автотранс-

\section{СПИСОК ЛІТЕРАТУРИ}

1. Колесник М. О. Національний реєстр хворих на хронічну хворобу нирок та пацієнтів з гострим пошкодженням нирок: 2016 рік. ДУІН НАМН України / М. О. Колесник. - Київ, 2017. - 201 с.

2. Кравець О. В. Хірургічні аспекти перитонеального діалізу: профілактика, діагностика та лікування ускладнень / О. В. Кра- плантації (у пацієнтів, яким не планується ниркова трансплантація і тільки при ВГПТ).

Субтотальну паратиреоїдектомію ми виконали у 7 (77,8 \%) пацієнтів, паратиреоїдектомію з авторансплантацією у 1 , та тотальну тиреоїдектомію без автотрансплантації у 1 пацієнта з важким ВГПТ, високим рівнем ПТГ (1850 пг/мл) та множинними переломами і деформацією скелета. При оперативному втручанні з приводу ВГПТ, згідно з рекомендаціями (S. E. Carty), обов'язково виконували інтраопераційну ревізію всіх ПЩЗ і тільки після цього визначали об' єм втручання. Зважаючи на гепаринотерапію у діалізних хворих, з метою адекватного інтраопераційного гемостазу застосовували біологічне зварювання тканин апаратом “Патон”.

За даними післяопераційного анкетування добрий результат з покращенням якості життя, компенсацією клініко-лабораторних показників досягнуто у 5 пацієнтів, яким виконано субтотальну резекцію ПЩЗ, задовільний результат (покращення якості життя, але не стійка компенсація лаборатоних показників) у 2 пацієнтів з субтотальною резекцією ПЩЗ та 1 з паратиреоїдектомією 3 автотрансплантацією; незадовільний результат констатовано у пацієнта після виконання тотальної тиреоїдектомії (компенсація лабораторних показників без помітного покращення якості життя). Летальних випадків серед вказаних пацієнтів після хірургічного лікування не спостерігали.

Висновки. Проведене дослідження підтверджує необхідність своєчасної діагностики та адекватного хірургічного лікування вторинного і третинного гіперпаратиреозу, який є частим ускладненням у пацієнтів 3 ХНH, що знаходяться на діалізному лікуванні.

Перспективи подальших досліджень. Важливою умовою ефективного хірургічного лікування ВГПТ і ТГПТ у пацієнтів з ХНН є стандартизація клініко-лаборатоних, інструментальних критеріїв і визначення груп ризику до хірургічного лікування, визначення персоніфікованого об’єму операції та алгоритмів післяопераційної реабілітації на основі довготривалого комплексного спостереження.

вець, І. А. Мисловський, В. М. Попадинець // Український медичний часопис. - 2018. - 3(2) (125). - T V/VI. - C. 40-43.

3. Применение перитонеального диализ как метода коррекции уремического синдрома у пациентов с хронической болезнью почек / В. Н. Лесовой, Н. М. Андоньева, Е. А. Гуц [и др.] // Междунар. мед. журн.- 2007. - № 3. - С. 95-100. 
4. Хирургическое лечение гиперпаратиреоза у больных с хронической болезнью почек, находящихся на программном гемодиализе / И. В. Макаров, Р. А. Галкин, А. В. Лукашова [и др.] // Таврический медико-биологический вестник. - 2017. -
T. 20, № 3. - С. 177-183.

5. Карти С. Э. Атлас эндокринной хирургии / С. Э. Карти ; пер. с англ. / под ред. Д. Г. Бельцевича. - М. : Логосфера, 2019. - 336 c.

\title{
REFERENCES
}

1. Kolesnyk, M.O. (2017). Natsionalnyi reiestr khvorykh na khronichnu khvorobu nyrok ta patsiientiv z hostrym poshkodzhenniam nyrok: 2016 rik [National Register of Patients with Chronic Kidney Disease and Patients with Acute Kidney Injury: 2016]. Kyiv [in Ukrainian].

2. Kravets, O.V., Myslovskyi, I.A., \& Popadynets, V.M. (2018). Khirurhichni aspekty perytonealnoho dializu: profilaktyka, diahnostyka, ta likuvannia uskladnen [Surgical aspects of peritoneal dialysis: prevention, diagnosis and treatment of complications]. Ukrainskyi medychmyi chasopys - Ukrainian Medical Herald, 3(2) (125) -V/VI, 40-43 [in Ukrainian].

3. Lesovoy, V.N., Andonyeva, N.M., \& Guts, E.A. (2007). Primeneniye peritonealnogo dializa kak metoda korrektsii uremicheskogo sindroma u patsiyentov s khronicheskoy boleznyu po-

chek [The use of peritoneal dialysis as a method of correction of uremic syndrome in patients with chronic kidney disease]. Mezhdunar. med. zhurn. - International Medical Journal, 3, 95-100 [in Russian].

4. Makarov, I.V., Galkin, R.A., \& Lukashova, A.V. (2017). Khirurgicheskoye lecheniye giperparatireoza u bolnykh s khronicheskoy boleznyu pochek, nakhodyashchikhsya na programmnom gemodialize [Surgical treatment of hyperparathyroidism in patients with chronic kidney disease undergoing hemodialysis]. Tavricheskiy medico-biologicheskiy vestnik - Taurian Medical and Biological Bulletin, 20 (3), 177-183 [in Russian].

5. Karti, S.Ye. (2019). Atlas endokrinnoy khirurgii [Atlas of endocrine surgery]. Beltsevich, D.G. (Ed.). Moscow: Logosfera [in Russian].

Отримано 19.11.2019

V. I. DESYATERIK, S. P. MIKHNO, O. V. ZALOZNY, A. M. LITVIN

Dnipropetrovsk Medical Academy

\section{SURGICAL PROBLEMS OF SECONDARY AND TERTIARY HYPERPARATHYROIDISM IN DIALYSIS PATIENTS WITH CHRONIC RENAL FAILURE}

The aim of the work: to improve the results of surgical treatment of secondary and tertiary hyperparathyroidism in patients with chronic renal failure in treatment of chronic hemodialysis.

Materials and Methods. The study was conducted on the basis of examination of medical records and 89 patients treated at the Department of Nephrology, City Clinical Hospital No. 2, Kryvyi Rih for 2014-2018. All patients were treated CKI using dialysis methods. Among the patients of group 166 (74.2\%) patients were on hemodialysis (HD), the group $2-23$ (25.8\%) on peritonal dialysis (PD). In both groups, men predominated by sex: 49 (55.1\%) and 40 (44.9\%), respectively. The mean age of patients in group 1 with PD was (35 \pm 6.4$)$ years, group 2 -

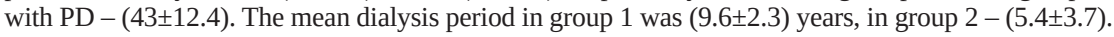

Results and Discussion. Among the main criteria for the surgical treatment of hypeparathyroidism in dialysis patients, clinical, laboratory, and instrumental indicators were identified.

Key words: chronic renal failure; secondary hyperparathyroidism; tertiary hypeparathyroidism; parathyroidectomy.

\section{В. И. ДЕСЯТЕРИК, С. П. МИХНО, А. В. ЗАЛОЗНЫЙ, А. М. ЛИТВИН}

КУ “Днепропетровская медицинская академия МОЗ Украины”

\section{ХИРУРГИЧЕСКИЕ ПРОБЛЕМЫ ВТОРИЧНОГО И ТРЕТИЧНОГО ГИПЕРПАРАТИРЕОЗА У ДИАЛИЗНЫХ ПАЦИЕНТОВ С ХРОНИЧЕСКОЙ ПОЧЕЧНОЙ НЕДОСТАТОЧНОСТЫЮ}

\begin{abstract}
Цель работы: определение распространенности гиперпаратиреоза у пациентов с хронической почечной недостаточностью (ХПН), проходивших лечение с использованием диализных технологий и анализ результатов его хирургического лечения. Материалы и методы. Исследование проведено на основе изучения медицинской документациии 89 пациентов, которые лечились в отделение нефрологии городской клинической больницы № 2 города Кривого Рога за 2014-2018 гг. Все пациенты проходили лечение ХПН с применением диализных методов. Среди пациентов первой группы 66 (74,2 \%) больных были на гемодиализе (ГД), второй - 23 (25,8 \%) на перитонеальном диализе (ПД). В обеих группах преобладали мужчины: соответственно 49 (55,1 \%) и 40 (44,9 \%) - женщины. Средний возраст пациентов первой группы по ГД составлял (35 $\pm 6,4)$ года, второй с ПД - $43 \pm 12,4$. Средний срок диализа в первой группе составлял $(9,6 \pm 2,3)$ года, во второй $-5,4 \pm 3,7$.

Результаты исследований и их обсуждение. Среди основных критериев для хирургического лечения гиперпаратиреоза диализных пациентов определены клинические, лабораторные и инструментальные показатели.
\end{abstract}

Ключевые слова: хроническая почечная недостаточность; вторичный гиперпаратиреоз; третичный гиперпаратиреоз; паратиреоидэктомия. 